\title{
Content Analysis on Potential Character Inclusion in Listening I Course Syllabus and Materials
}

\author{
Hidayah Nor \\ UIN Antasari Banjarmasin, Indonesia
}

Abstract: The development of programs of study, learning and teaching resources, lesson plans and assessment of students, and even teacher education are all based on curriculum. In addition, the integration of character education in the curriculum and learning process carried out from the planning, implementation, and evaluation of learning in all subjects and it can be adopted in making lesson planning (syllabus, lesson plans and teaching materials). Since character education has recently become an important issue in the Indonesian education system, this research examines the potential incorporation of the character education in Listening 1 course syllabus and materials by having content analysis. The findings reveal that there are 18 characters of education that can be applied in the syllabus, they are Caring and Compassionate, Creative, Curious, Democratic, Discipline, Empathy, Honest, Inclusion/Communicative, Independent, Love Peace, Love Reading, Love the Nation, Nationalistic, Religious, Responsible, Sportive and Respectful, Tolerant, and Work hard. Those characters are incorporated in the 10 topics (Meeting people for the first time, Families, Numbers, Let's eat, Free time, Gifts, Part time jobs, Celebration, Invention, and Folktales) and also included in Introduction, Self Study, Expansion, Middle test and Final Test of Listening 1 course materials.

Keywords: Content Analysis, Character Inclusion, Listening 1 Course

\section{INTRODUCTION}

Curriculum is the foundation of the teaching-learning process. The development of programs of study, learning and teaching resources, lesson plans and assessment of students, and even teacher education are all based on curriculum. According to De Coninck (2008), curriculum, more than ever before, is now viewed as being at the centre of daily life and the responsibility of society as a whole.

The phrase character education refers to almost anything that schools might try to provide outside of academics, especially when the purpose is to help children grow into good people and teach them in order to have a good character based on the purpose of education itself. Character education has recently become an important issue in the Indonesian education system. Some schools developed special programs called character education. Every school, teacher, and staff has the freedom to manage and choose how character education has been taught to its students. 
In relation with the teaching of English as a Foreign Language in Indonesia particularly in English Education Department of Faculty of Tarbiyah and Teachers Training at UIN Antasari Banjarmasin, the teaching of listening focuses on equipping students with the skills and strategies in listening and familiarizing the students with spoken English and letting them hear different varieties and accents.

Listening is taught in a courses series beginning with Listening 1, Listening 2, and Listening 3 at English Education Department of Faculty of Tarbiyah and Teachers Training at UIN Antasari Banjarmasin. Listening 1 course focuses on employing strategic skills to recognize meaningful English sounds and their elements, and also to comprehend simple utterances with different varieties and accents of English.

It is very important to prepare the students to be able to produce language fluently and accurately from the materials that they have heard independently and also the lecturer should include the good characters in syllabus and teaching materials because it is very important to build the students' characters even at the university level to teach the students to become better humans in the future.

This research focused on the analysis of potential character education inclusion in the Listening 1 syllabus and materials because the researchers thought that it is very important to include the character building in teaching and learning process and teach the students about the characters both implicitly and explicitly through the listening activities so that the students are not only getting the knowledge of listening skills but also can get the value of the characters for them.

\section{Research Questions} follow:

Based on the above background, the problems of this research are as

1. Which character education is actually addressed in Listening 1 course Syllabus and teaching materials?

2. To what extent does the Listening 1 course syllabus and teaching materials incorporated character education in its content?

3. To what extent these characters are promoted in the classroom?

\section{Research Purposes}

1. Identifying the character education addressed in the Listening 1 course syllabus and teaching materials.

2. Investigating incorporation of the character education in Listening 1 course syllabus and teaching materials based on the listening topics.

3. Assessing the frequency of occurrence for each of these characters education in the classroom when the listening topics are taught to the students.

\section{Research Significances}

1. It is hoped to add to the existing literature on the inclusion of character education in the activities of teaching Listening.

2. It is used as a stepping stone in improving the quality of the Listening syllabus and materials by giving beneficial suggestions related to how to include the 
character education activities in the listening 1 course materials for the second semester students of English Education Department.

3. It is expected that the findings will help the English teachers and lecturers in selecting the materials and take this study into consideration about the appropriate Listening materials for their students.

\section{LITERATURE REVIEW}

Curriculum is a set plan and arrangement about purpose, content, and lesson materials and as a guidance to manage study activity in reaching the purpose of certain education. This specific purpose covers the goal of national education with its specification, condition, and area potency, school and participant. In addition, curriculum is also the compilation of a set of education to enable program adjustment with the requirement and potency in certain area.

Meanwhile, syllabus is a guidance to conduct teaching learning activity including classroom management as well as evaluation. Syllabus consists of elements: indicators, concept, learning activity, media and evaluation.

Character education is an investment system of the character values of the school citizens which includes the components of knowledge, awareness or volition, and action to implement these values to the God, ourselves, others, environment, and nationality. Character education in schools, all the components should be involved, such as the content of curriculum, learning and assessment, relationships quality, school management, the implementation of activity, infrastructure, financing, and all citizens working and school environment.

In accordance with Law No 20 in 2003 on National Education System in Article 3, which states that the national education serves to develop skills and form the character and civilization of the nation's dignity in the context of the intellectual life of the nation. On the other hand, the research at Harvard University in the United States (Ali Ibrahim Akbar, 2000), it turns out a person's success is 20 percent by the knowledge and technical skills (hard skills), but 80 percent by the ability to manage ourselves and others (soft skills). This suggests that the quality of students' character education is very important to be improved.

Character building is very important to be developed by the society and considered as an effective answer to the problems faced by Indonesians nowadays. It does not place human's intelligence as the main target but it shapes students to be humanistic. By giving character building in education particularly in teaching English, the students will not only have a good intelligence but also have their own character.

Building students' character is not only the duty of the teachers (school) but also all elements surrounding the students must support this program. Therefore, for the school in applying character building should involve parents and also community as partners in educating students in order to have positive character. The difference between educated and uneducated people depends on how they treat other people. 


\section{The Definition of Character Education}

There are some definitions of character education, including:

1. Character education is a national movement creating schools that foster ethical, responsible, and caring young people by modeling and teaching good character through emphasis on universal values that we all share. It is the intentional, proactive effort by schools, districts, and states to instill in their students important core, ethical values such as caring, honesty, fairness, responsibility, and respect for self and others (Character Education Partnership).

2. Character education is teaching children about basic human values, including honesty, kindness, generosity, courage, freedom, equality, and respect. The goal is to raise children to become morally responsible, self-disciplined citizens. (Association for Supervision and Curriculum Development)

3. Character education is the deliberate effort to develop good character based on core virtues that are good for the individual and good for society. (Thomas Lickona)

4. Character education is any deliberate approach by which school personnel, often in conjunction with parents and community members, help children and youth become caring, principled, and responsible. (National Commission on Character Education)

Character is a psychological construct. That is, the outcome of effective character education is the psychological development of students. Character education targets a particular subset of child development, which we call character. Character is the composite of those psychological characteristics that impact the child's capacity and tendency to be an effective moral agent, i.e. to be socially and personally responsible, ethical, and self-managed.

Character education then ought to be most effective if it relies predominantly on those social, education, and contextual processes that are known to significantly impact the psychological development of such characteristics.

1. Social skills and awareness (e.g., communications skills, active listening, relationship skills, assertiveness, social awareness).

2. Personal improvement/Self-management and awareness (e.g., self-control, goal setting, relaxation techniques, self-awareness, emotional awareness)

3. Problem-solving/Decision-making.

\section{Implementing Character Building in Lesson Plan}

Integration of character education in the learning process carried out starting from the planning, implementation, and evaluation of learning in all subjects. Among the principles to be adopted in making lesson planning (syllabus, lesson plans and teaching materials), carry out the learning process, and evaluation are the principles of Contextual Teaching and Learning that had been introduced to teachers, including school teachers throughout Indonesia since 2002.

It is generally lesson plan composed as formulated in the syllabus, learning objectives, learning materials, teaching methods, learning steps, learning resources, and assessments that are developed in the lesson plan are basically chosen to create the learning process to achieve the Standard Competence and 
Basic Competence. Therefore, the teachers' lesson plans in creating a learning perspective on development of character need to be adapted into the following:

1. Additions / modification of the learning objectives so that learning does not only help learners reach Base Competence, but also to develop their character

2. Additions / modification of learning activities so that there are learning activities that develop learners' character.

3. Additions / modifications indicators so that there are indicators of achievement related to student achievement in terms of character

4. Additions / modification of existing assessment techniques so that the assessment techniques that can be developed / measure the development of character.

\section{The examples of Integrated Basic Character Values in Lesson plan}

In this section, the researchers presented several examples of integrated character values and the indicators reflect in the training or English language learning activities (teaching materials).

\section{Politeness}

Indicators: Respond to and express politeness

Teaching materials: Please open the door (expression of politeness)

2. Honesty

Indicators: Request and give correct information

Teaching Materials: Where is the post office? (asking about direction)

\section{Confidence}

Indicators: Reading aloud with correct pronunciation and intonation

Teaching materials: Read the text aloud

\section{Social Care}

Indicators: Greet people who are already / not yet known

Teaching materials: The expression greeting like "Hello," Good morning ", etc.

5. Religiosity

Indicators: Expressed his sympathy in writing on religious experience Teaching materials: The expression of sympathy and greeting text: "Happy Fitri Day" and "Merry Christmas"

6. Intelligence (think logically, critically and creative)

Indicators: Doing a monologue in the form of descriptive

Teaching materials: Tell your friends about the food you prefer most.

\section{Cooperation}

Indicators: Having short conversation in pairs

Teaching materials: Make a conversation and perform it in pairs

8. Respect

Indicator: Displaying written work to be appreciated / comment

Teaching materials: Please put the result of your discussion on the wall and let your friends give their critical comments.

9. Democracy

Indicator: Asking opinion

Teaching materials: What do you think about? 


\section{RESEARCH METHOD}

Since the study focuses on the analysis of the content document materials, it is designed as descriptive-qualitative content analysis. Gay, Borg and Gall (1983) define content analysis as "a research technique for the objective, systematic, and quantitative description of the manifest content of communication." So, content analysis is a kind of study that needs document or written data, i.e. printed forms or books as sources of data.

According to Best (1981:106-107), "the analysis is concerned with the explanation of the status of some phenomenon at a particular time or its development over a period of time. One of the purposes of content or documentary analysis is to evaluate bias, prejudice, propaganda in a textbook presentation." Thus, when using documentary sources, it should be consider that data appearing in print are not necessarily trustworthy, so that the validity of its content needed to be questioned.

This research used content analysis to determine the potential inclusion of character education in the Listening 1 course syllabus and teaching materials.

All the topics of syllabus and materials of Listening 1 course are closely examined to identify the potential incorporation of the character education. The analysis is conducted along the criteria of incorporation, distribution and balance of the various characters in these activities. The unit of analysis is the topic and the category of analysis is the types of characters in each of the topics in the Listening 1 course syllabus and teaching materials.

To establish the validity of the list of activities used in the analysis, it is given to the experts in curriculum to ascertain its appropriateness for the purposes of the research. The expert's feedback, which constituted of suggestions to rephrase, add or delete items, is used to modify the list prior to the analysis. Intrarater reliability of the content analysis is also ascertained through test-retest.

\section{Research Subject}

In this research, the subject of the data analysis is the syllabus and teaching materials. It means the document is already available. The researchers tried to find out whether the character building reflects in the syllabus and materials. Then, the researchers gave recommended topics, materials and assignments that reflect character education, and insert some values in the character education proposed by the government in the syllabus and materials.

\section{The Sources of Data}

The main sources of data in this research are the syllabus and teaching materials of Listening 1 course. The syllabus consists of sixteen meetings including introduction, self-study, expansion, middle test and final test and the listening materials consist of ten topics they are meeting people for the first time, families, numbers, let's eat, free time, gifts, part time jobs, celebration, invention, and folktales. In this case, the researchers took the topics of the materials that reflect character building values. 


\section{The Data Collection}

The research has been done by the researchers as the main evaluator. The data of this study are in the form of syllabus and teaching materials of Listening 1 course. All of the descriptions of the character building values based on Ministry of Education and Culture help the writer in collecting the data. Then, the researchers made some indicators to identify the character education values in the syllabus and teaching materials that consist of key words, inference, writer's tone, and theme.

\section{The Data Analysis}

The researchers use the character buildings types based on National Education Department and there are 18 values of character building in national character and cultural education as the instruments, namely;

1. Religious

2. Honest

3. Tolerant

4. Discipline

5. Work hard

6. Creative

7. Independent

8. Democratic

9. Curious

10. Nationalistic

11. Love the Nation

12. Sportive and Respectful

13. Inclusion / Communicative

14. Love Peace

15. Love Reading

16. Caring and Compassionate

17. Empathy

18. Responsible.

The researchers identified and categorized the materials in syllabus that are suitable with the list of 18 values of character education proposed by National Education Department. If the topics in the syllabus do not contain the values, the researchers inserted some values that can be developed.

The researchers used components of data analysis by using flow model. Analysis consists of three con-current flows of activity: data reduction, data display, and conclusion drawing / verification based on Miles and Huberman (1994) which were conducted during and after data collection.

\section{FINDINGS AND DISCUSSION}

This part deals with the result of the research based on some facts found in the data. The researchers analyzed the potential character education inclusion in the Listening 1 syllabus and materials. There are three research questions that should be answered in this part. 


\section{The character education addressed in the activities of the Listening 1 course syllabus and teaching materials.}

After reviewing the syllabus of Listening 1 course, the researchers found that the character education did not include in the syllabus, thus the researchers decided to revise the syllabus and include some important character education that is appropriate based on the topics that will be taught to the students.

The table below showed the old version of Listening 1 course syllabus without the character inclusion in it, the syllabus just consisted of three important points, there are meeting, specific objectives, and topics, and for the addition column, the researchers added the character education for the topics that the students will learn. In addition, the character education also include in introduction part, middle test, final test, expansion, and self-study activities because it is very important for the students as their enrichment and evaluation of listening skills.

Thus, the character inclusion focused on 10 topics of listening 1 course materials, they are: Meeting people for the first time, Families, Numbers, Let's eat, Free time, Gifts, Part time jobs, Celebration, Invention, and Folktales.

Table 1. The new Syllabus of Listening 1 course that already include character education

\begin{tabular}{|c|c|c|c|}
\hline Meeting & Specific Objectives & Topics & Character Inclusion \\
\hline 1. & $\begin{array}{l}\text { The students should be able to } \\
\text { understand Listening I subject } \\
\text { description }\end{array}$ & $\begin{array}{l}\text { Introduction } \\
\text { Types of Listening and } \\
\text { Pre Test }\end{array}$ & $\begin{array}{l}\text { 1. Discipline } \\
\text { 2. Democratic } \\
\text { 3. Curious } \\
\text { 4. Caring and } \\
\text { Compassionate } \\
\text { 5. Tolerant }\end{array}$ \\
\hline 2. & $\begin{array}{l}\text { The students should be able to } \\
\text { comprehend the listening } \\
\text { materials entitled "meeting } \\
\text { people" }\end{array}$ & $\begin{array}{l}\text { Meeting people (Unit 1) } \\
\text { a. Warming Up } \\
\text { b. How about you? } \\
\text { c. Around the world } \\
\text { d. Getting to know you } \\
\text { e. Where are you from? } \\
\text { f. About you } \\
\text { g. Real Stories }\end{array}$ & $\begin{array}{l}\text { 1. Honest } \\
\text { 2. Work hard } \\
\text { 3. Creative } \\
\text { 4. Independent }\end{array}$ \\
\hline 3. & $\begin{array}{l}\text { The students should be able to } \\
\text { comprehend the listening } \\
\text { materials entitled "Families" }\end{array}$ & $\begin{array}{l}\text { Families (Unit 2) } \\
\text { a. Warming Up } \\
\text { b. Families Photos } \\
\text { c. Family Ties } \\
\text { d. My Family }\end{array}$ & $\begin{array}{l}\text { 1. Curious } \\
\text { 2. Sportive and Respectful } \\
\text { 3. Caring and } \\
\text { Compassionate } \\
\text { 4. Empathy } \\
\text { 5. Love Peace }\end{array}$ \\
\hline 4. & $\begin{array}{l}\text { The students should be able to } \\
\text { comprehend the listening } \\
\text { materials entitled "Numbers" }\end{array}$ & $\begin{array}{l}\text { Numbers (Unit 3) } \\
\text { a. Warming Up } \\
\text { b. On the Phone } \\
\text { c. Team Scores } \\
\text { d. Numbers, numbers } \\
\text { e. What are you } \\
\text { shopping for? } \\
\text { f. About You }\end{array}$ & $\begin{array}{l}\text { 1. Honest } \\
\text { 2. Work hard } \\
\text { 3. Independent } \\
\text { 4. Sportive and Respectful }\end{array}$ \\
\hline 5. & $\begin{array}{l}\text { The students should be able to } \\
\text { comprehend the listening } \\
\text { materials entitled "Let's eat" }\end{array}$ & $\begin{array}{l}\text { Let's eat (Unit 4) } \\
\text { a. Warming Up } \\
\text { b. What would you }\end{array}$ & $\begin{array}{l}\text { 1. Curious } \\
\text { 2. Nationalistic } \\
\text { 3. Love the Nation }\end{array}$ \\
\hline
\end{tabular}




\begin{tabular}{|c|c|c|c|}
\hline & & $\begin{array}{l}\text { like? } \\
\text { c. This looks great! } \\
\text { d. The food game } \\
\text { e. A great recipe } \\
\text { f. About you }\end{array}$ & \\
\hline 6. & $\begin{array}{l}\text { The students should be able to } \\
\text { comprehend the listening } \\
\text { materials entitled "Free Time" }\end{array}$ & $\begin{array}{l}\text { Free Time (Unit 5) } \\
\text { a. Warming Up } \\
\text { b. How Often? } \\
\text { c. What's popular? } \\
\text { d. My Free time }\end{array}$ & $\begin{array}{l}\text { 1. Discipline } \\
\text { 2. Work hard } \\
\text { 3. Creative } \\
\text { 4. Independent }\end{array}$ \\
\hline 7. & $\begin{array}{l}\text { The students should be able to } \\
\text { do self-study (unit 1-5) and } \\
\text { comprehend the } \\
\text { supplementary listening } \\
\text { materials }\end{array}$ & $\begin{array}{l}\text { Self-Study (Unit 1-5) } \\
\text { Supplementary Materials }\end{array}$ & $\begin{array}{l}\text { 1. Discipline } \\
\text { 2. Work hard } \\
\text { 3. Creative } \\
\text { 4. Independent } \\
\text { 5. Responsible }\end{array}$ \\
\hline 8. & & $\begin{array}{l}\text { Middle Test / Quiz (Unit } \\
\text { 1-5) }\end{array}$ & $\begin{array}{l}\text { 1. Honest } \\
\text { 2. Responsible } \\
\text { 3. Independent } \\
\text { 4. Discipline } \\
\text { 5. Work Hard }\end{array}$ \\
\hline 9. & $\begin{array}{l}\text { The students should be able to } \\
\text { comprehend the listening } \\
\text { materials entitled "Gifts" }\end{array}$ & $\begin{array}{l}\text { Gifts (Unit 12) } \\
\text { a. Warming Up } \\
\text { b. Gift-giving } \\
\text { occasions } \\
\text { c. Gifts and cultures } \\
\text { d. Gift Exchange }\end{array}$ & $\begin{array}{l}\text { 1. Sportive and Respectful } \\
\text { 2. Caring and } \\
\text { Compassionate } \\
\text { 3. Empathy }\end{array}$ \\
\hline 10. & $\begin{array}{l}\text { The students should be able to } \\
\text { comprehend the listening } \\
\text { materials entitled "Part-time } \\
\text { jobs" }\end{array}$ & $\begin{array}{l}\text { Part-time jobs (Unit 13) } \\
\text { a. Warming Up } \\
\text { b. What's the job? } \\
\text { c. Job Interviews } \\
\text { d. My Ideal job } \\
\text { e. What do you want to } \\
\text { do? } \\
\text { f. About you } \\
\text { g. Real stories }\end{array}$ & $\begin{array}{l}\text { 1. Discipline } \\
\text { 2. Work hard } \\
\text { 3. Creative } \\
\text { 4. Independent } \\
\text { 5. Responsible. }\end{array}$ \\
\hline
\end{tabular}

The students should be able to
comprehend the listening
11. "Celebrations"
"Caterials entitled

Real stories

Celebrations (Unit 14) 1. Religious
a. Warming Up
b. Fireworks, food, and
2. Nationalistic fun
3. Love the Nation
4. Love Peace

c. Celebration time

d. Holiday memories

The students should be able to comprehend the listening materials entitled "Inventions"

12.

Inventions (Unit 15)

1. Creative
2. Independent
3. Curious
b. What's the invention?
c. What's it for?
d. Thank you, Mr. Robot?

a. Warming Up

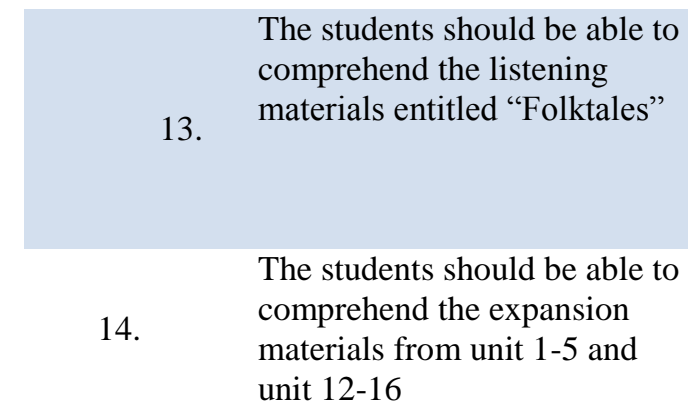

Folktales (Unit 16)
a. Warming Up
b. The farmer and his sons
2. Nationalistic
The stonecutter
3. Love the Nation
4. Love Reading

d. Once upon a time...

Expansion 1 Thailand

1. Creative

a. Listening Task 1

2. Curious

Information

b. Listening Task 2

3. Love Reading

4. Inclusion/ 
Food

Expansion 3 Italy

a. Listening Task 1

Information

b. Listening Task 2

University Life

Expansion 4 India

a. Listening Task 1

Information

b. Listening Task $2 \mathrm{~A}$

Festival

The students should be able to

do self-study (unit 12-16) and

15. comprehend the

supplementary listening

materials

16.
Self-Study (Unit 12-16)

Supplementary Materials

.

Final Test / Quiz (Unit

12-16)
Communicative

1. Discipline

2. Work hard

3. Creative

4. Independent

5. Responsible

1. Honest

2. Responsible

3. Independent

4. Discipline

5. Work Hard

Based on the table above, the characters education inclusion for each topic of the listening 1 materials are based on the consideration of the researchers after reviewing the topics that will be taught to the students, the researchers have already discussed it with the expert of the Listening 1 course and made it suitable for the students' need of character education in their teaching and learning process. Thus, the numbers of the characters that are included are different with each topic, the maximum numbers are five characters, and the minimum ones are three characters.

The next is about the content of students' books of Listening 1 course has been included character education principles. The researchers have tried to arrange the textbooks based on the characters education inclusion of the syllabus and teach the characters to the students for every topic in the book that has been agreed before. The figures below show the sample materials for each topic and the materials can be in audio or video formats, depends on the topics chosen. 


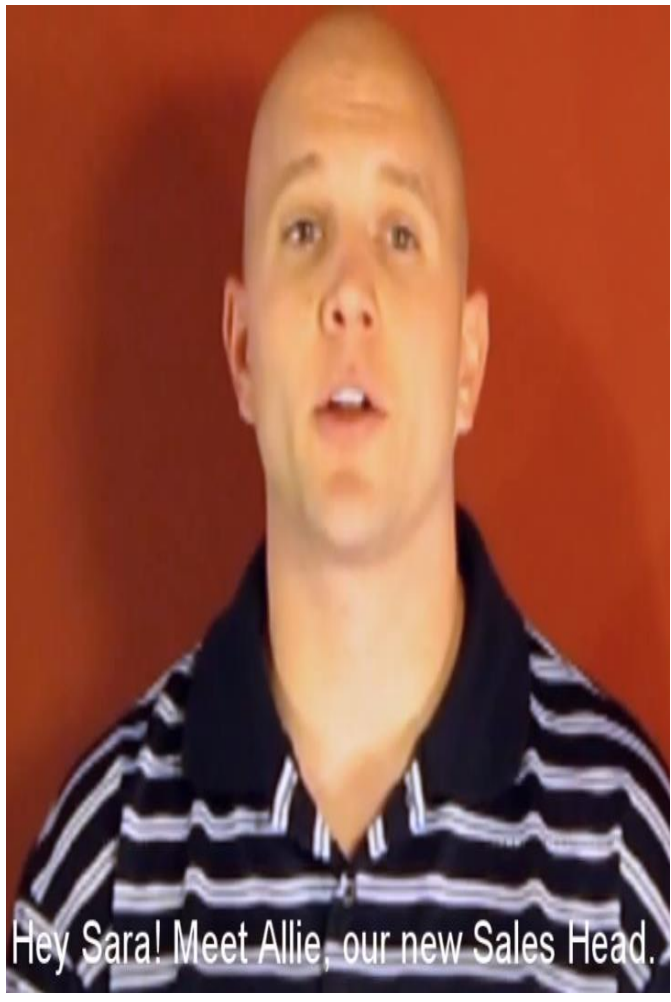

Figure 1. Meeting People for the First Time

\section{Family photos}

MAINIDEA $\mathbf{A} B$ Listen. People are talking about their families. Who are they talking about? Check $(\checkmark)$ the correct pictures.
10
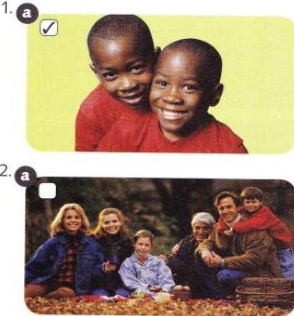

-
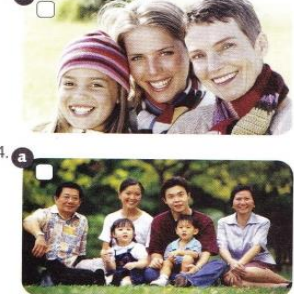
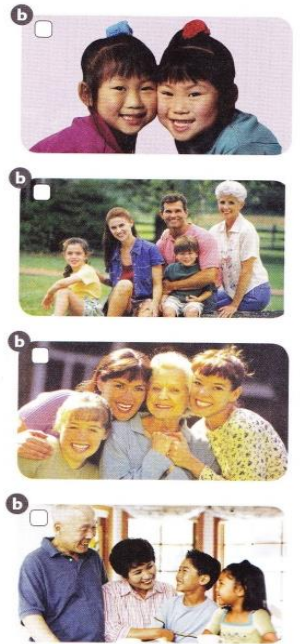

DEralls $\mathbf{B}$ Listen again. Circle the correct information.

1. The woman likes to take them to eat hamburgers / pirza

2. His parents live nearby / far away.

3. The picture was taken at her niece's / mother's birthday party.

4. The granddaughter likes / doesn't like school.

Figure 2. Families

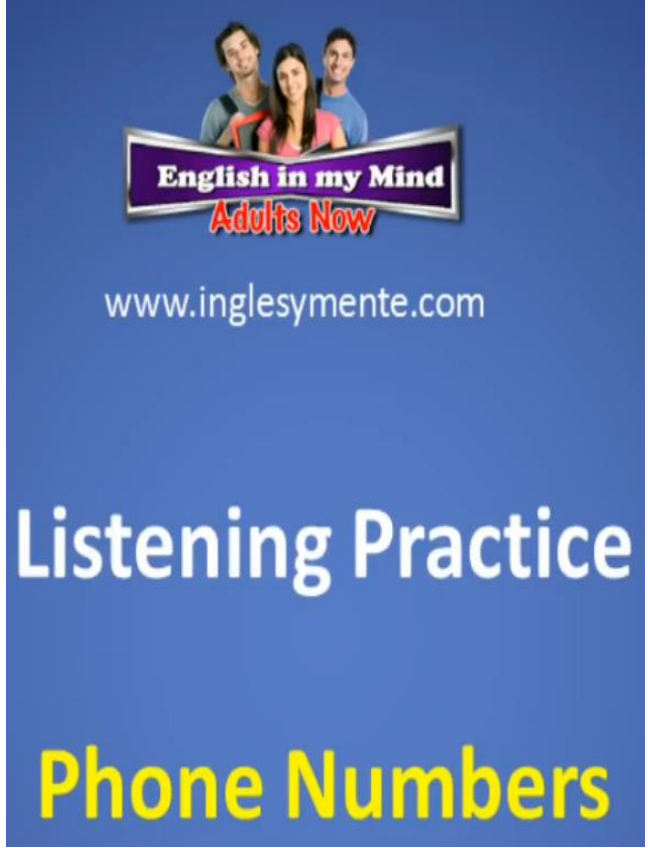

Figure 3. Numbers

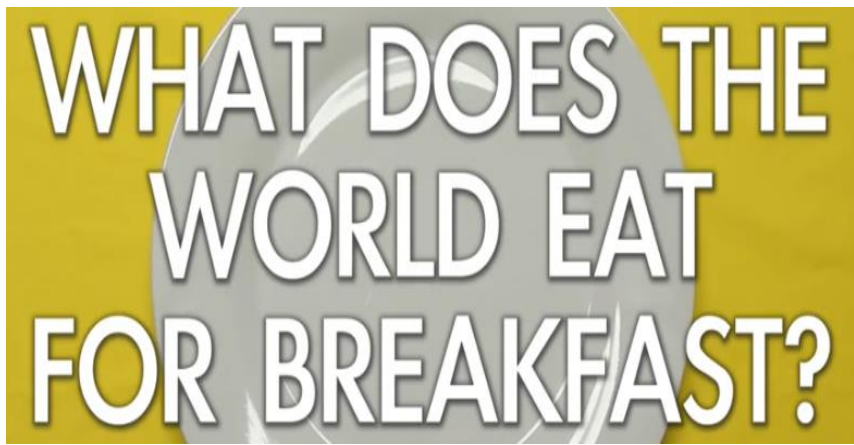

Figure 4. Let's eat

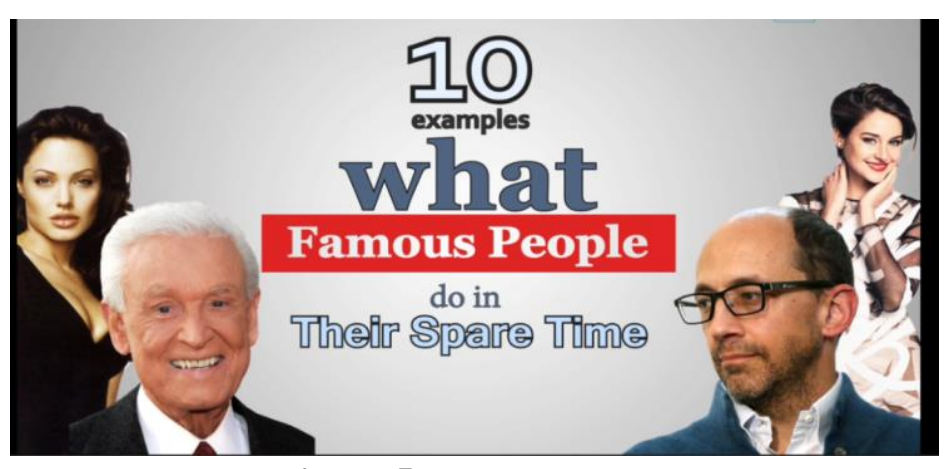

Figure 5. Free Time 


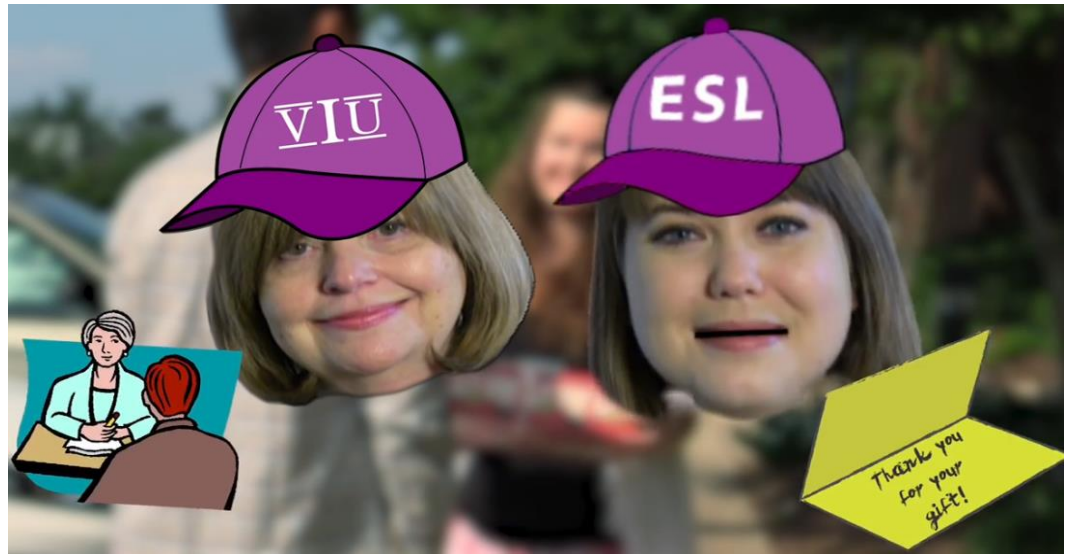

Figure 6. Gifts

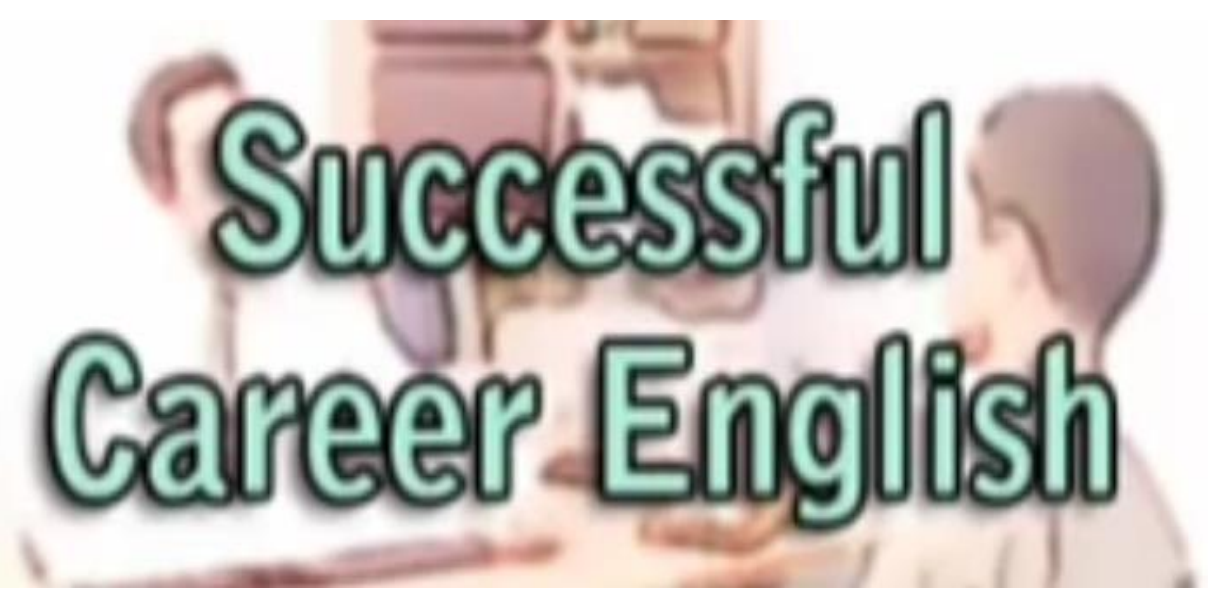

Figure 7. Part Time Jobs

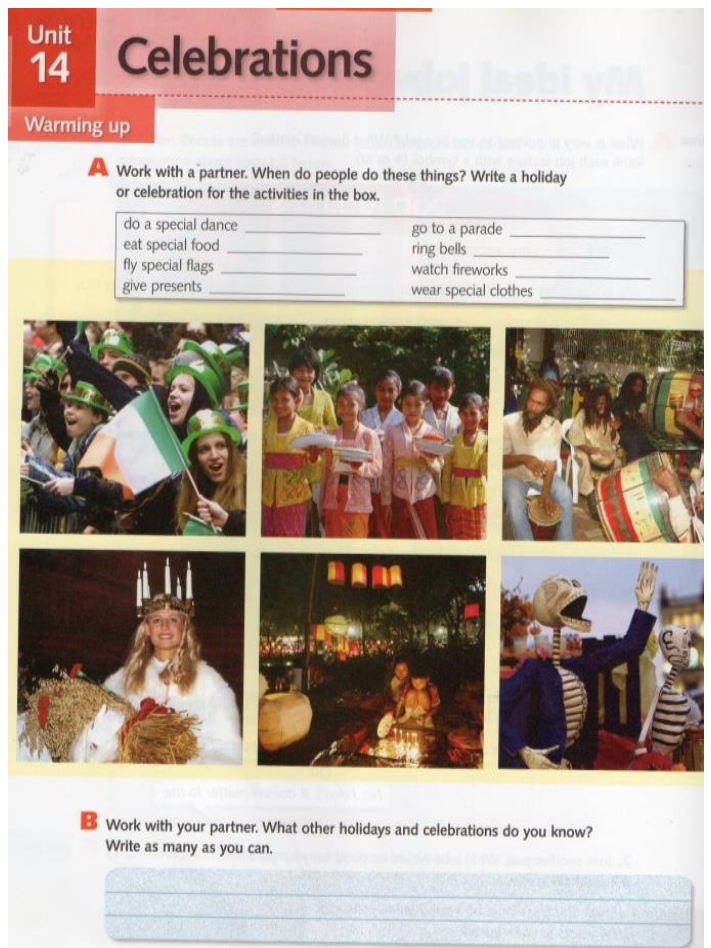

Figure 8. Celebration

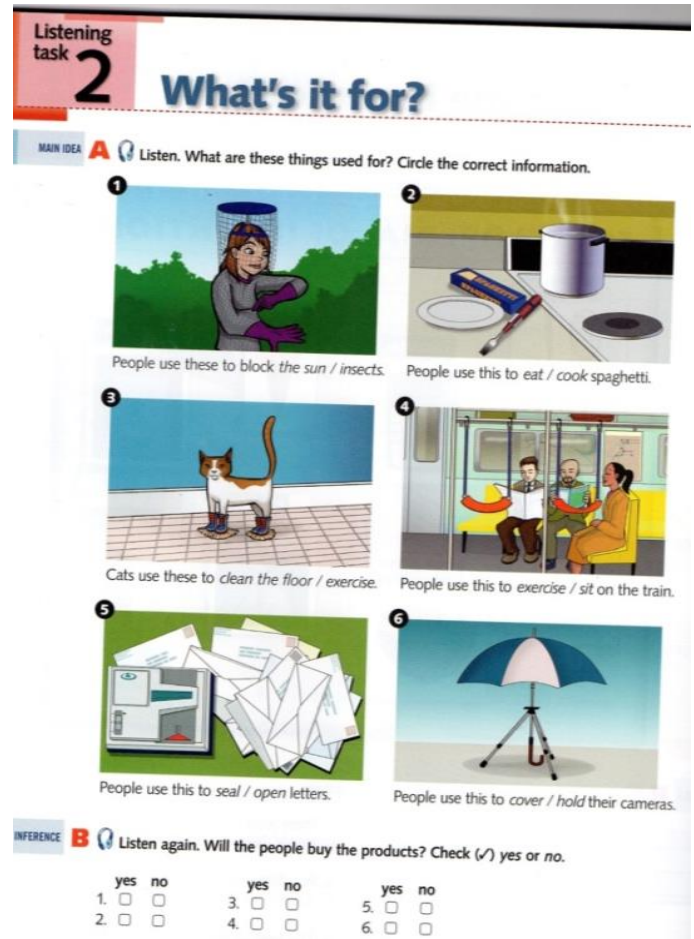

Figure 9. Invention 


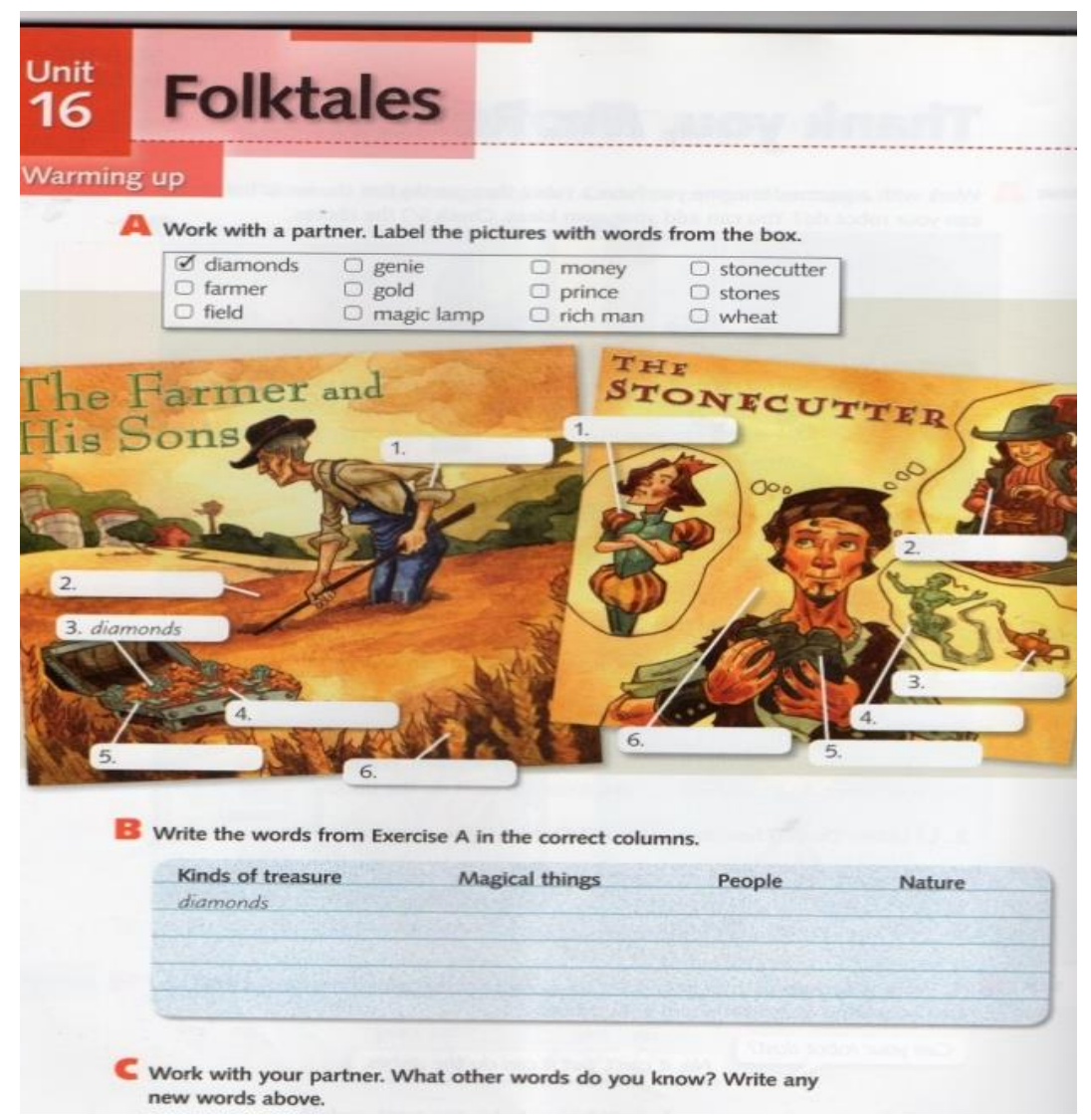

Figure 10. Folktales

Based on the syllabus and the sample materials for each topic of Listening 1 course, it can be concluded that the researchers attempted to include the character education for every activity in teaching and learning process. While listening to the materials and answering the questions on their text books, the students are taught the characters education that should be owned in their daily life. The characters can be applied in the pre listening, while listening, or in post listening stages it depends on the lecturer and students' needs.

\section{Incorporation of the character education in Listening 1 course syllabus and teaching materials}

The second question of this research has been answered by the researchers after revising the syllabus and providing the materials for Listening 1 course that include the characters education appropriate with the topics given to the students. 


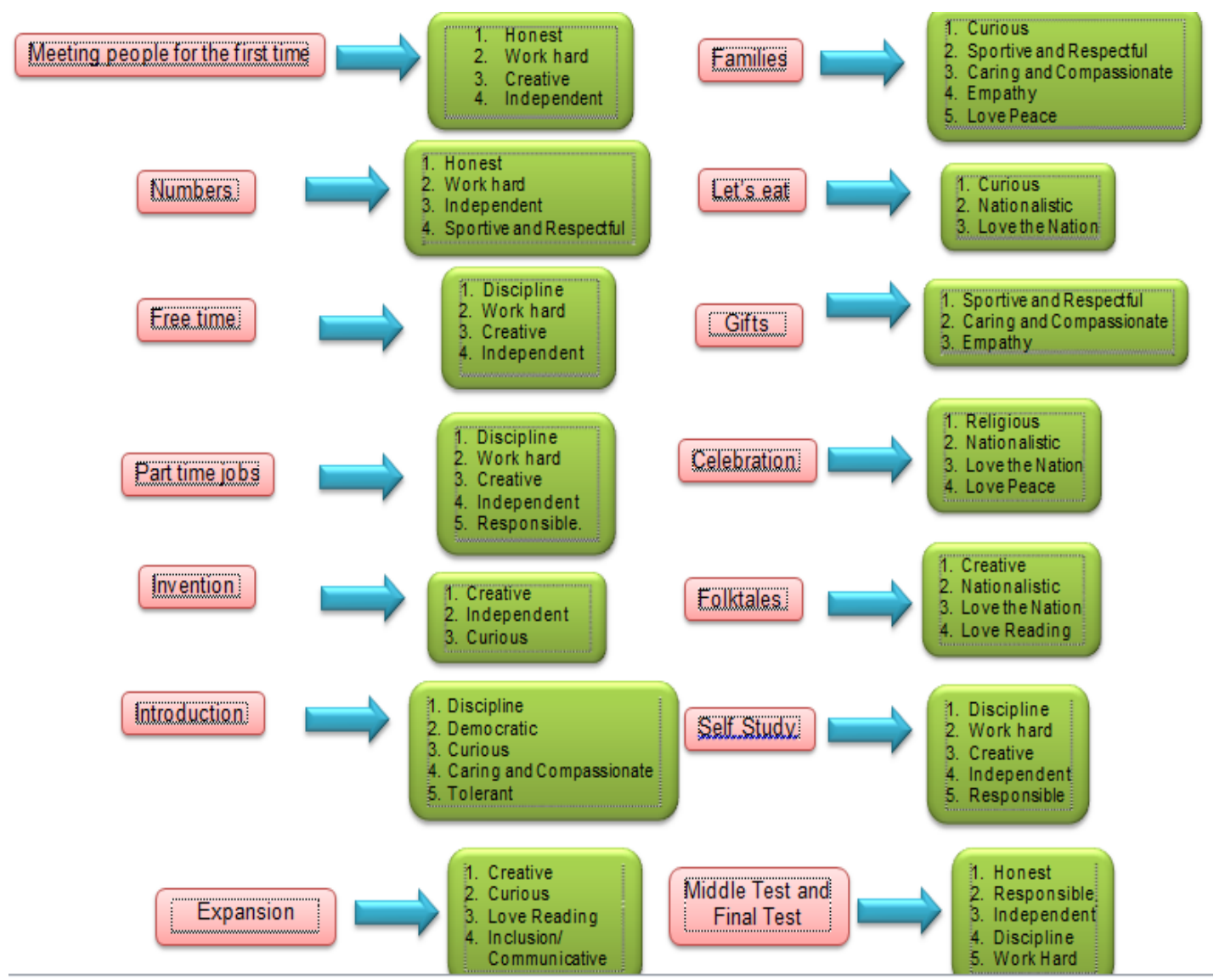

Figure 11. The Topics of Listening 1 course and the characters inclusion for each topic

As it can be seen there are ten topics of listening 1 course: Meeting people for the first time, Families, Numbers, Let's eat, Free time, Gifts, Part time jobs, Celebration, Invention, and Folktales, and there are also introduction, self-study, expansion, middle test and final test. There are 68 characters education inclusion for those topics. The incorporation of the characters are different each other based on the needs of the students and the maximum numbers of the characters for the topics are 5 characters in the topic Part Time Jobs, Families, Introduction, selfstudy, middle test and final test. The minimum numbers are 3 characters in the topics Lets' Eat, Gifts, and Invention.

\section{The frequency of occurrence for each of these characters education in the classroom.}

There are 18 characters education that can be included in the syllabus and teaching materials of Listening 1 course after analyzing and reviewing the syllabus by the researchers, the characters are as follow:

1. Caring and Compassionate

2. Creative

3. Curious

4. Democratic

5. Discipline

6. Empathy

7. Honest

8. Inclusion/Communicative 

9. Independent
10. Love Peace
11. Love Reading
12. Love the Nation
13. Nationalistic
14. Religious
15. Responsible
16. Sportive and Respectful
17. Tolerant
18. Work hard

Based on the theory of characters education that should be included in the teaching and learning process, there are 18 characters included in the syllabus and appropriate for the topics that have been already prepared for the second semester students of Listening 1 course. For the next time or for the next courses of Listening or other skills, it might be included more characters for each topic of the lesson, so there might be six or more characters included in the topics.

The table below showed the frequency and the percentage of the characters inclusion in Listening 1 course syllabus and teaching materials.

Table 2. Characters Inclusion based on the Frequency and Percentage

\begin{tabular}{lcc}
\hline \multicolumn{1}{c}{ Character Inclusion } & Frequency & Percentage \\
\hline Caring and Compassionate & 3 & $4.40 \%$ \\
& & $11.76 \%$ \\
Creative & 8 & $7.35 \%$ \\
Curious & 5 & $10.29 \%$ \\
Discipline & 7 & $1.47 \%$ \\
Democratic & 1 & $2.94 \%$ \\
Empathy & 2 & $5.88 \%$ \\
Honest & 4 & $1.47 \%$ \\
Inclusion/Communicate & 1 & $13.23 \%$ \\
Independent & 9 & $2.94 \%$ \\
Love Peace & 2 & $2.94 \%$ \\
Love Reading & 2 & $4.40 \%$ \\
Love the Nation & 3 & $4.40 \%$ \\
Nationalistic & 3 & $1.47 \%$ \\
Religious & 1 & $7.35 \%$ \\
Responsible & 5 & $4.40 \%$ \\
Sportive and Respectful & 3 & $1.47 \%$ \\
Tolerant & 1 & $11.76 \%$ \\
Work hard & 8 & $100 \%$ \\
\hline
\end{tabular}

Based on the table above, it can be seen that the most frequent character involved is independent which has 9 frequencies and the percentages are $13.23 \%$ for each character. It happened because the researchers and the lecturers of Listening 1 course promoted the students' independence in the classroom and it should be taught often to the students not only in listening skill but also for other skills such as speaking, reading, and writing. 
The least characters that are included in the lesson are democratic, inclusion/communicate, religious and tolerant which have only once in every topic and the percentages are $1.47 \%$. It happened due to those characters are already taught in other courses and other skills and the listening topics did not really need the characters applied in the classroom. The finding of this research is in line with the previous study was conducted by Sutiah (2008). She investigated the development of teaching materials for Islamic subject based on character building with regard to contextual approach (CTL) in senior high school students grade X in Malang. The result of her research findings showed that this teaching material was effective with the need and condition of the user. She finally concluded that could improve learning achievement in some aspect or performance in the teaching and learning activity of Islamic education based on character education with contextual approach.

\section{CONCLUSION}

This research has been conducted for analyzing the potential inclusion of potential character education inclusion in the Listening 1 syllabus and materials and it reached three important points for the concluding remarks.

1. There are 18 characters education addressed in the Listening 1 course syllabus and teaching materials, they are Caring and Compassionate, Creative, Curious, Democratic, Discipline, Empathy, Honest, Inclusion/Communicative, Independent, Love Peace, Love Reading, Love the Nation, Nationalistic, Religious, Responsible, Sportive and Respectful, Tolerant, and Work hard.

2. The incorporation of the character education in Listening 1 course syllabus and teaching materials can be found in the 10 topics of Listening (Meeting people for the first time, Families, Numbers, Let's eat, Free time, Gifts, Part time jobs, Celebration, Invention, and Folktales) and also included in introduction, selfstudy, expansion, middle test and final test. The maximum numbers of the characters for the topics are 5 characters in the topic Part Time Jobs, Families, Introduction, self-study, middle test and final test. The minimum numbers are 3 characters in the topics Lets' Eat, Gifts, and Invention.

3. The most frequent character involved is independent which has 9 frequencies and the percentage is $13.23 \%$. On the other hand, the least characters are democratic, inclusion/communicate, religious and tolerant which have only once in every topic and the percentages are $1.47 \%$.

\section{ACKNOWLEDGMENTS}

The author would like to express appreciations to Colleagues who always accompany me to discuss about my research, and UIN Antasari Banjarmasin particularly English Education Department team for their valuable comments and other help.

\section{REFERENCES}

Ary, D.,Jacobs, L.C., \& Razavieh, A.(2002). Introduction to Research in Education (6th edition). Belmont: Wadsworth. 
Berelson, B. (1971). Content Analysis in Communication Research. New York: Hafiner Publishing Company.

Borg, W.R. \& Gall, M.D. (1983). Educational Research: An Introduction. New York: Longman.

Dubin, F, \& Olshtainm E.(1996). Course Design: Developing Program and Materials for Language Learning. New York, U SA: Cambridge University Press.

Goodnan, J.F. \& Lesnick, H. (2004). Moral Education: A Teacher-Centered Approach. Boston: University of Pennisylvania.

Kesuma, D., Triatna, C., \& Pramana, J. (2011). Pendidikan Karakter: Kajian Teori \& Praktik di Sekolah. Bandung: PT. Remaja Rosdakarya.

Krippendorff, K.(1980). Content Analysis: An Introduction to Its Methodology. London: Sage Publications.

Kweldju, S. (2011). Extensive Reading for English Proficiency Improvement, Character Development, and Peace Education. Paper presented on the Third National English Language Teachers and Lecturers (NELTAL) conference conducted at the State University of Malang on March 26, 2011.

Kulsum, U. (2011). Implementasi Pendidikan Karakter Berbasis PAIKEM (Sebuah Paradigma Baru Pendidikan di Indonesia). Surabaya. Gena Pratama Pustaka.

Miles, B.M \& Hubberman, A. (1994). An Expanded Sourcebook: Qualitative Data Analysis. Second Edition. California: Sage Publication Ltd.

Muslich, M. (2011). Pendidikan Karakter: Menjawab Tantangan dan Krisis Multidimensional. Jakarta: PT. Bumi Aksara.

Noor, R.M. (2011). Pendidikan Karakter Berbasis Sastra : Solusi Pendidikan Moral Yang Efektif. Jogjakarta. Ar-Ruzz Media.

Priyana, J. (2002). Developing EFL Task-Based Language Instruction in an Indonesian Primary School Context. Unpublished Dissertation.

Pusat Kurikulum dan Perbukuan. (2011). Panduan Pelaksanaan Pendidikan Berkarakter. Jakarta: Kementrian Pendidikan Nasional.

Richards, J. (2001). Curriculum Development in Language Teaching. New York: Cambridge University Press.

Stamlerm S. (2001). An Introduction to Content Analysis, (online). ("http//writing.colostate.edu/references/ research/content downloaded August 24, 2010).

Sutiah, (2008). Pengembangan Mode Bahan Ajar Pembelajaran Pendidikan Agama Islam Berbasis Pendidikan Karakter dengan Pendekatan Kontekstual Di SMA Kelas X Kota Malang. Unpublished Dissertation. Malang: State University of Malang.

Tomlinson, B. (Ed.). (1998). Materials Development in Language Teaching. Cambridge: Cambridge University Press. 